3 ) K. Balakrishna Iyer, R. M. Phatarfod; J. Text. Inst., 56, T225 (1965-5)

4) J. W. S. Hearle, et al; J. Text. Inst., 52, T 197 (1961-5)

5 ) L. R. G. Treloar, et al; J. Text. Inst., 53, T 446 (1962-9)

6 ) L. R. G. Treloar, et al; J. Text: Inst., 54, T $156(1963-4)$
7) W. F. Kilby; J. Text. Inst., 55, T589 (196412)

8) H. W. Holdaway; J. Text. Inst., 56, T 121 (1965-3)

9) J. W. S. Hearle; Text. Res. J., 35, 1060(1965 -12)

10) 我妻; 基礎絨維工学, p 285.(1965-10) 繊維機械 学会

\title{
討論会記 録
}

〔質問 1】紡績系中の䋐維が同心円層内に位置せず, 転位を生ずるのは撚かけ機構によるあのか，あるいは 粗糸中の繊維配列によるものか. むし前者とすれば， 撚かけ時のどんなアクションによるのか.

〔回 答〕たとえ䋐維が完全に平行な粗系であって あ, フロントローラから出て加撚されると, 加然に より生ずる内部圧力に内外層間の不均斉が起こり, 圧 力の弱い部分の繊維が逐次外層へ押し出されて, 転位 を生ずる・とうして内部圧の均斉化が行なわれる. 定 性的には，乙のように説明されているが，ロービング 構造と転位構造との対応や, 転位モデルの統計的考察 は, 今後の課題である・（井谷, 川端）

\section{[質問 2]}

（1）糸のバルキ加工は，平行繊維を乱すととによる 含気率の増加が狙いである.このように糸軸と直角 方向の繊維軸成分が系の見かけ太さに関係を持つと 思われるが，この考え方の導入はできないか.

（2）毛羽の多い系でメリヤスを編むと，バルキな製 品ができるが, 毛羽が系の見かけ太さに及ぼす影響 はどうか. また, アクリルのバルキ系のループ状緎
維の場合はどうか.

〔回 答〕この質問の趣旨は，系の太さに及ぼす毛羽 之巻縮の効果を求める問題であると思う. 系にバル キ構造を与えるための毛羽や巻縮は, 外力に対して あバルキ構造を保持できる腰老持つ必要があり, こ れは繊維のねじり剛性率により定まる・ねじり剛性 率は，等方性物質ではヤング率の $1 / 3$ であるが，繊維 のような異方性物質では延伸を大きくするほど小さ くなって，バルキ性を保持する力が失なわれる・バ ルキ構造を与えようと思えば，延伸倍率を下げるこ とである・（藤本枝太）

〔質問 3〕単系, 双系, 三子などの撚構造が，糸の物 性に及ぼす影響を研究した例があるか。

\section{[回 答]}

1) 真鍋; 繊機誌, 9, 35 (1956-1)

2) G. Dakin; J. Text. Inst., 48, T293(1957-7,8)

3) L. A. Fiori, et al; Text. Res. J., 24, 526 (1954 $-6)$

4) " $\quad$ " 24, 428(1954-5)

5) " $\quad$ " 24, $267(1954-3)$

6 ) N. Roper; Text. Manuf., 84, 395 (1958-8)

\section{（b） スライバ粗系の空隙構造とその性質}

壁馬大学学部 下茂武

\section{1.はじめに}

スライバ粗系の太さと構造およびプロセシシグという 表題を頂戴したが，空隙を指定しない繊維の集合体では 太さを定義しにくいので，本報前半では集合体の空隙構
造について述べたい. 紡績が天然繊維を取扱った時代に は, 原料によって空隙が固有の值をもっていて, 番手と いう概念で太さが表示できたのであろう. その結果, た とえば産地別の綿から何番手の系をどのように紡ぐかと いうプロセシングは経験的に確立していた。現在では, 
素材が同じです長さやクリンプが烡なり，硬軟の材質が

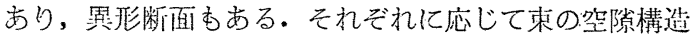

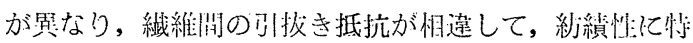
長的湆影響する。この過程の解析之休采化之为望志しい のであるが，今日まだ確立したすのはない，本報後半で はスライバの空隙による延伸举動について実験結果を述 べて参若に供したい。

\section{2. 集合体空隙の測定}

Ritter-Drake の水銀插入法によって試料の空隙率 $\varepsilon$ 之P Pore Size の分布が測定される。 スライバ状符合体 の繊維間空陌の測定には $1 \mathrm{~mm} \mathrm{Hg} \sim 2 \mathrm{~atm}$ の圧力範柬 で十分である，第 1 図に示すように，カード上がりの綿 スライバでは自然状態で $(1-\varepsilon)=0.13$ で䋱孔半径は $5 \sim 25 \mu$ に大部分が分布しており，その最大頻度值は $r_{m}=10 \mu$ の程度である. 乙れを径方向に圧縮すると $r_{m}$ はスライバ密度の增加に対して直線的に減少し, 充実度 $(1-\varepsilon)=0.4$ くらいでは $r_{m}=7.5 \mu$ となる.またス

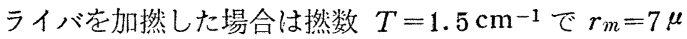
に達し，それ以上撚数を増すと Pore Size にはほとん ぞ変化がなく, 袈陌率 $\varepsilon$ が著しく減少する. 織布の場合

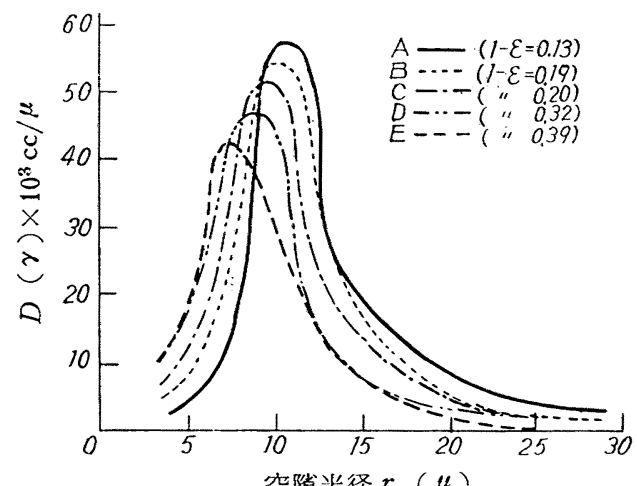

（第1四）圧縮されたスライバの空隙分布

は, 組織によって空陌率は異なるが, Pore Size の分布 には 2 つの極大值があり，15〜20 $\mu$ 付近の山は系相互間 の空隙を示し, $r_{m}=5 \mu$ 付近のものが繊維相互間の值 であると推定される．乙れら 2 つの空隙分布の山は布の ストレッチ性を支配するあのとして重要である，以上の 結果から平行瀻維束では充実度 $(1-\varepsilon)=0.4$ までは接 触繊維自身の径方向の圧縮は起こらず，それ以上に充実 度が増すと束断面を横切る繊維群にクラスタ一状の部分 集合が生じて，クラスター内の Pore Size が $7 \sim 5 \mu$
程度のあのよなると考えてよいであろう。クリンプはと のクラスター集合を均一化するの代有效である。

\section{3. 空隙構造と集合体物性}

定まった繊維から作られた集合体の物性は，之の配向 坐と空吵とを主因子とした構造の関数として定められ る. 構造内を Mass, Energy, Momentum などが輸送 される場合の集合体特性について $2 ， 3$ の例をあげてお $<$.

\section{1 通 気性}

単位時間の流量と圧力勾配の比として湘定される通気 係数 Permeability は, 多孔質空間の複雑な Geometry あるいは Texture を反胦しており，その定量的な関係 づ村には構造模型の理想化が必要である。この理想化は Equivalent Capillarie をどのように定めるかによる。 すなわち直径 $b$ の円形断面加らる瀻維の集合体におい て, 細孔半径 $r$ は空隙率 $\varepsilon$ に対してどのように変化する か, 纎維断面が円形でも一様ですない子き互均直径 $b$ を い加に選ぶべきか，また空隙における流れの径路はどう なっているかなどの点が規定されなければならない．

一般に，粘性係数 クの流机に対する通気係数を $B=$ $B_{0} / \eta$ とすれば

$$
B_{\theta}=\varepsilon r_{m}^{2} / k
$$

で与えられる.ここに $r_{m}$ は空隙の Hydraulic Radius, $k$ は流れ抵抗を示す Kozeny 因子である。平行または ランダムの繊維束に対して，てれらの因子はつぎのよう 亿定められる，断面の形状のいかれによらず, 要素瀻維 の単位体積当たりの表面積 (Specific Surface) を $S_{\mathbf{0}}$ と すると $r_{m}=\varepsilon / S_{0}(1-\varepsilon)$ である。 また試料内流路の 属曲長 (Tortuosity) を $\left(L_{e} / L\right)$ とすれば $k=\left(L_{e}\right)$ $L)^{2} k_{0}$ である. ただし $L$ は試料の流れ方向の厚さ， $L_{e}$ は試料内毛管の実際の長さ， $k_{0}$ は要素の断面形状にはよ ら妙みられる定数である. 要素繊維が直径 $b$ の円简状 の場合は $S_{0}=4 / b$ であるから式（1）は

$$
B_{0}=\frac{b^{2}}{16 k} \frac{\varepsilon^{3}}{(1-\varepsilon)^{2}}
$$

となる. 各種繊維束における実験によれば $k_{0} \approx 2$ で, 平 行配向のとき $\left(L_{e} / L\right)=1$, またランダム配向では $\left(L_{e} /\right.$ $L)^{2}=1.5 \sim 2.5$ である. $k$ の值は充実度 $(1-\varepsilon)$ が小 さいとき $5 \sim 6$ の程度で, $(1-\varepsilon)>0.4$ では $k \approx 2<$ らいに低下する．また空陌率 $\varepsilon$ の一定の集合体では要素 繊維の材質が剬いほど $k$ の值は大きいため， $k$ は Stiffness の尺度としても用いられる. 測定值の例を第 1 表に 
（第 1 表） 緎維束の Kozeny 因子

\begin{tabular}{c|c|c}
\hline \hline 試 & $1-\varepsilon$ & $k$ \\
\hline 綿の平行䋐維: 束 & 0.2 & 2.4 \\
羊毛の " & 0.3 & 1.6 \\
羊毛のランダム束 & 0.3 & 6.1 \\
黄麻の " & 0.4 & 5.2 \\
\hline
\end{tabular}

示した.

\section{2 透 電 性}

集合体を極板の間に入れて電気容量の空気に対する变 化 $\Delta C=C-C_{0}$ を測定するとき, $\Delta C$ の值は䋐維の方向 分布 $f(\theta)$ や空陌率 $\varepsilon$ 亿関係する. 計算によれば要素 繊維の誘電率が $E$ の集合体では

$$
\begin{aligned}
\frac{\Delta C}{C_{0}^{-}} & =\left\{f_{1}(\theta)(\varepsilon-1)\right. \\
& \left.+f_{2}(\theta)\left(1+\frac{2}{\pi}\right) \frac{E-1}{E+1}\right\}(1-\varepsilon)
\end{aligned}
$$

となる. 繊維が板に垂直のとき $f_{1}(\theta)=1, f_{2}(\theta)=0$ 平行配向のとき $f_{1}(\theta)=0, f_{2}(\theta)=1$, ランダムな らば $f_{1}(\theta)=0.378, f_{2}(\theta)=0.622$ である. 乾燥した スフの繊維束における測定結果を第 2 図に示した。極板

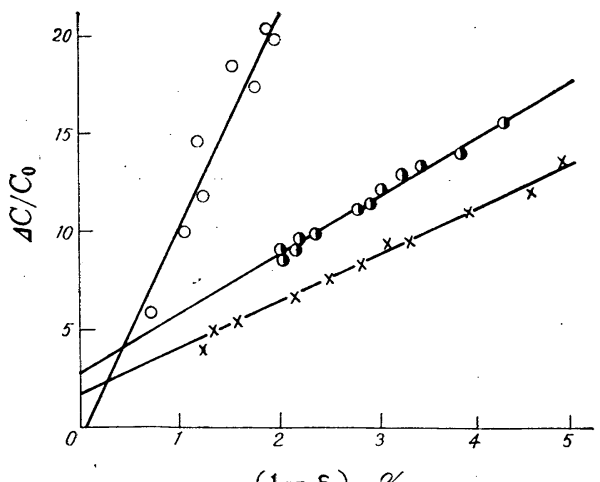

○垂直配向， ランダム配向， $\times$ 平行配向

（第 2 図） スライバ束の透電性と充実度の関係

の End Effect のため測定値は図の原点を通らないが,

(3) 式の関係は成り立つととが認められる：各配向の 場合の勾配加ら求められる繊維の透電率の值は $E=8 \sim$

\section{1 である。}

\section{3 熱 伝 尊性}

空気の熱伝導率を $k_{a}$ ，繊維のそれを $k_{f}$ とした場合， 空隙率 $\varepsilon$ の集合体の熱伝導率 $k$ は (3) 式と同様にして

$$
\begin{array}{r}
k=k_{a}+\left\{f_{1}(\theta)\left(k_{f}-k_{a}\right)+f_{2}(\theta) \cdot\right. \\
\left.\left(1+\frac{2}{\pi}\right) k_{a} \begin{array}{c}
k_{f}-k_{a} \\
k_{f}+k_{a}
\end{array}\right\}(1-\varepsilon) \ldots . .
\end{array}
$$

で与えられる， $f_{1}(\theta), f_{2}(\theta)$ は繊維の方向分布で定 まる係数である. 充实度 $(1-\varepsilon)$ が増加するとき, 集 合体の伝繁率 $k$ の值は， $k_{f}>k_{a}$ なら増加し， $k_{f}<k_{a}$ な らば減少する，笑験によれば熱板に平行配向の乾燥木 綿スライバの蒸伝導率 $k$ は充実度に刘して第 3 図の之 おりに減少する。図において $k$ が空気压によって異な り，各気圧において充実度が大となると直線からの外れ が現われ, 充実度 $(1-\varepsilon)>0.3$ ではほぼ平衡值に近 づく.とれは空文の伝導率 $k_{a}$ の值が空気分子の平均自由 行程 lの大きさによって異なるからである.すなわち瀻 維のないときの空気の自由行程を $l_{0}$ とし, 直径 $b$ の緎 維加らなる空隙の Pore Size Diameter $d=2 r_{m}$ とすれば

$$
l=l_{0}\left(1-e^{-\pi ! l 0}\right), \quad d=\frac{\pi^{2} \dot{b}}{8} \frac{\varepsilon}{1-\varepsilon}
$$

であって, 充実度 $(1-\varepsilon)$ が増すほど $d$ は小となり, 織維の存在によって $l$ は減少する，空気圧が一定のとき $k_{a}$ は $l$ に比例するから, 充実度の堌すほど $k_{a}$ は小さ く，その結果，集合体の伝尊率 $k$ の $(1-\varepsilon)$ に対する

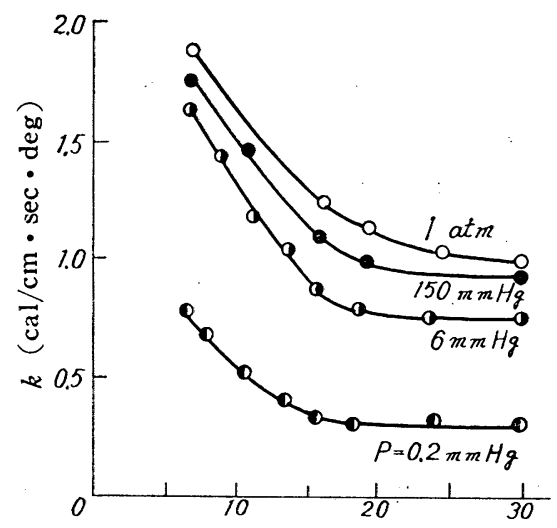

充実度 $\xi(\%)$

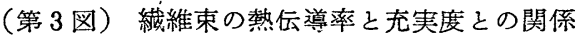

低下の勾配は少なくなるまま（5）式より繊維が細い ほど $k_{a}$ は小となり，集合体の保温性がよくなるととあ わかる.

このように, 集合体のみかけの熱伝導率 $k$ は, 空陌 率，配向性および Pore Size Diameter に関係する。と くに繊維が密に接触するとみられる $(1-\varepsilon)$ が $0.3 \sim$ 
0.4 以上では $k$ は空気分子の承均自由行程 $l$ にって支 配されるととが注目される。

\section{4 束内瀻維の引抜力}

集合休に与えられる機珹的刺激之応答との関係を微視 的に観れば, 要素瀻維の変形之要素相互間の張力伝達の メカニズムとに帰着する．異なった条件のもとで束から 䉾織維を引き妨く要する力は, 乙の伝達機構の素過程 として重要なむのである. 一般に, 引抜力 $F$ は接触点の 数 $n$ と, その離抜の強さ $x$ とで定められ

$$
F=\int_{(x)} x n(x) d x=\bar{n} \bar{x}
$$

之表わされる. $\bar{x}$ は切線方向の摩擦力之垂直方向の粘着 力であって, 接触圧 $p$, 接触の曲率 (加撚試料では撚数 $T$ ), 相対速度 $V$ に依存する. $\bar{n}$ は架陌率 $\varepsilon$, 繊維長 $l$, 臬径 $b$, 屈曲度 (または方向分布 $f(\theta)$ ) で定まり

$$
\begin{aligned}
\bar{n} & =\frac{4}{\pi} \frac{l}{b}(1-\varepsilon)\left(2 \overline{\sin ^{2} \theta} \overline{\cos ^{2} \theta}+\frac{1}{2}{\overline{\sin ^{2} \theta}}^{2}\right) \\
& \approx l(1-\varepsilon) /(2 b),(\theta \approx \pi / 2) \quad \cdots \cdots \cdots(7)
\end{aligned}
$$

で与えられる。

実験によれば, 束の充実度を指定したスライバでは, $(1-\varepsilon)<0.3$ の範围では $\bar{x}$ は一定值 $x_{0}$ と見なされる. 乙の場合の引抜力を $F(0)$, 撚数 $T\left(\mathrm{~cm}^{-1}\right)$ のそれを $F(T)$, 引抜速度 $V$ の值を $F(V)$ とすれば，それぞれ

$$
\begin{gathered}
F\left(0,=x_{0}(1-\varepsilon), \quad F(T)=F(0)\left(a+b T^{2}\right),\right. \\
F(V)=\alpha \log \beta V \quad \ldots \ldots \ldots \ldots \ldots \ldots \ldots(
\end{gathered}
$$

となる.ただし $a, b, \alpha, \beta$ 忷摩擦定数である.ま た，束の表面圧力 $P$ を指定したスライバでは， $\bar{n} あ \bar{x} あ$ 繊維間接触圧 $p=2 b P /(1-\varepsilon)$ 之繊維間摩擦係数 $\mu$ を通じて定められ

$$
F i 0,=2 b \mu P /(1-\varepsilon)+\text { const. }
$$

となる.とてで $P \propto(1-\varepsilon)^{3}-\left(1-\varepsilon_{0}\right)^{3}$ であるから $(1-\varepsilon) \ll 1$ ならば $F(0)$ はほぼ $(1-\varepsilon)$ に比例す ろ.

なお束からの単繊維の引抜力は Stick-Slip 運動を行 ない, その振幅は静摩擦と動摩擦の差が大きいほど大き く, 周期は繊維のばね定数が小さいほど大きくなる。

\section{4. 繊維束の空隙と延伸挙動}

荷重による束の伸長や除荷による回復履歷などの, 短 い繊維の空隙性集合であるスライバの力学的性質は, 単 瀻維を束から引抜くときの性質と本質的には同一であ る.すなわち束の性質は単瀻維自身の弾性 $\left(10^{6} \mathrm{~g} / \mathrm{cm}^{2}\right.$ 程度）にはほとんど関係せず，引抜きの摩擦力（束で
$10^{3} \mathrm{~g} / \mathrm{cm}^{2}$ の程度) で与えられると考えてよい. 以下実 験例についててのととを示そう。

\section{1 束の荷重一伸長曲線 $P(\gamma)$}

$P(\gamma)$ は伸びはじひにわずかに戦性伸長したのち勾配 が大きくなって，そのままの勾配で伸びてゆき，最後に 勾配が平らになって切断する (第 4 図)。このととは束

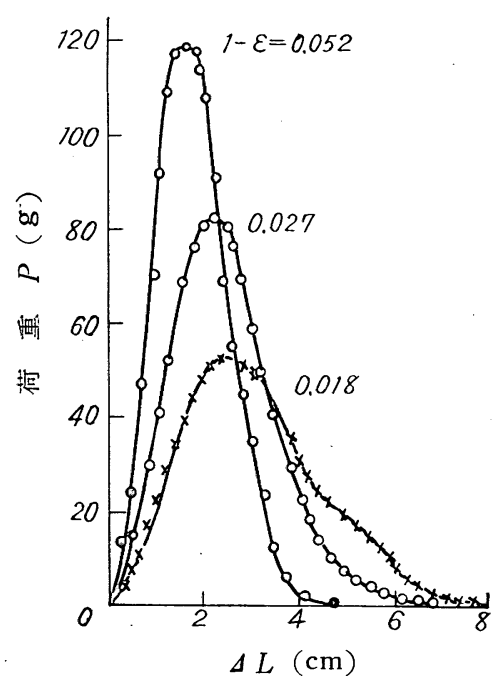

（第 4 図）スライバの荷重一伸張曲線

内の単綫維は最初撓んでいたものが荷重によって緊張 し, やがて繊維間には摩擦力が働いて, との摩擦力の総 和が束の張力を与えるに至るものと考えられる. 事実, 束の $P(\gamma)$ 曲線の勾配加束内瀻維 1 本当たりの張力 を求めてみると, $\gamma=0 \%$ 付近では単纎維の張力 $f$ は単 緎維の引抜摩擦力 $F$ の 1/1 程度であるし, また $f$ はまっ すぐの絾維を伸ばすときの張力の $1 / 1$ 程度のものとなる. ところが束の伸長が増して $P(\gamma)$ 曲線の勾配が増し, その大いさの変化がなくなる付近 $(\gamma=1 \%)$ では, 束 内繊維 1 本当たりの張力 $f$ は, 単繊維 1 本当たりの引抜 摩擦力 $F$ と Same Order となる. 乙の場合, 測定結果 によると束の充実度 $(1-\varepsilon)$ の值を大きくした束では $P(\gamma)$ 曲線の勾配が $(1-\varepsilon)$ に比例して大きくなる. したがって勾配から求めた束内瀻維の張力 $f$ 屯充実度 $(1-\varepsilon)$ に比例して大きくなるが, てれは単繊維の引 抜摩擦力 $F$ 之充実度 $(1-\varepsilon)$ の值とが比例関係にある という実験事実と一致する.

\section{2 束の切断荷重 $P_{m}$}

$P_{m}$ は, 束長 $L_{0}$ が長くなると減少し, $L_{0}$ が平均繊 維長 $\bar{l}$ の 4 倍ないし最大瀻維長 $l_{\max }$ の. 2 倍程度を越え 
ると、ほぼ変わらなくなる(第 5 図)。このことは長い 束の切断は 1 個所で起こり, 切断荷重はこの断面儿存在

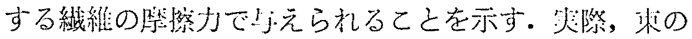
切断荷重 $P_{m}$ を䄉維数で制って求めた切断時の束内䋐維 1 本当たりの張力 $f$ は, 単織維の引拔摩擦力 $F$ と Same Order で, $f=P_{m} / \bar{N}$ は摩擦力 $F$ の約 $1 / 2 \sim 1 / 4$ となる (第 6 図)。実験によると単綫維の引拻摩擦力は，2本 同時に引抜く場合， 2 本を接触して揃えて引抜くと 1 本 の引抜力之同じで, $1 \mathrm{~mm}$ 以上 2 本を離して引抜くとき は 1 本の 2 倍となる.とのととから $f / F$ の比が $1 / 4$ とな るととが導かれる.すなわち束の切断際して断面には じめ $N$ 本あった繊維が $N / 2$ 本ずつの $A, B 2 つ の$ 繊維 群に分かれる. 束内繊維の交錯が不規則であるとすれ ば， $A$ 群に属する 1 本の繊維に対して $B$ 群に属する繊維 の交錯する確率は $1 / 2$ である.よって束の切断荷重 $P_{m}$ は

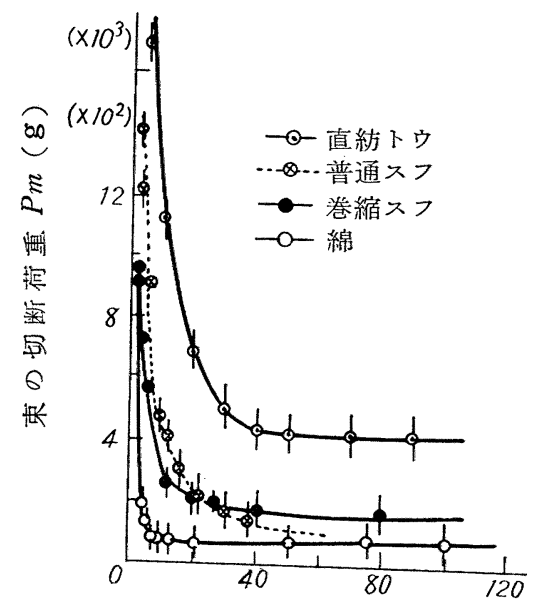

試 長 $L_{0}(\mathrm{~cm})$

（第 5 図）束の切断荷重之試長との関係

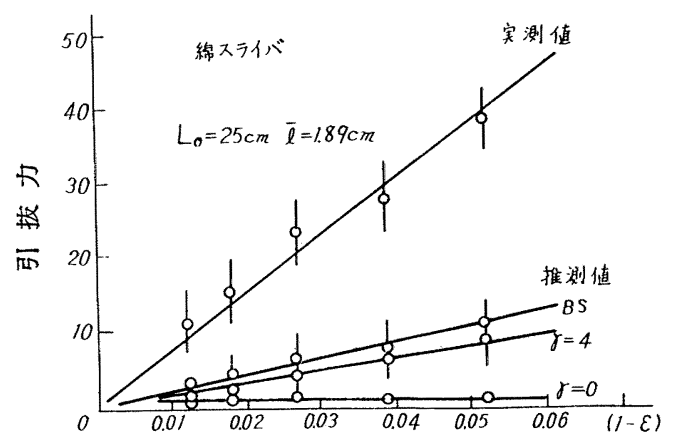

充実度

（第 6 図）束内㵶維の引拔力と充実度の関係

$$
P_{m}=F \times \frac{N}{2} \times \frac{1}{2}
$$

したがって， $f=P_{m} / N$ とすれば $f / F=1 / 4$ となる.な お切断荷重 $P_{m}$ の值は束の充実度 $(1-\varepsilon)$ に比例して 大きくなるが，乙れも引抜摩擦力と同じ性質である。

\section{3 除荷による束の回復性 $\phi\left(\gamma_{r}\right)$}

加重の途中で減荷することによって束の荷重一伸長曲 線には履歴が現われる．回復の履歴を表わす量としてレ ジリエンス $\phi=\left(L_{r}-L_{p}\right) /\left(L_{r}-L_{0}\right) \times 100$ （\%) を用い

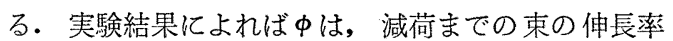
$\gamma_{r}=\left(L_{r}-L_{0}\right) / L_{0}$ が大きくなると，直線的に減少する (第 7 図). このととは束を伸長するほど東内の繊維は 摩擦力に抗して余計ずって扔り, 減荷によって䋐維間の ずれは回復しないととを示している．またレジリエンス $\phi は, \gamma_{r}$ が一定の場合, 束長 $L_{9}$ が短いほど大きくなる (第 8 図).乙れは $L_{0}$ が短くなって平均繊維長 $\bar{l}$ 亿近く

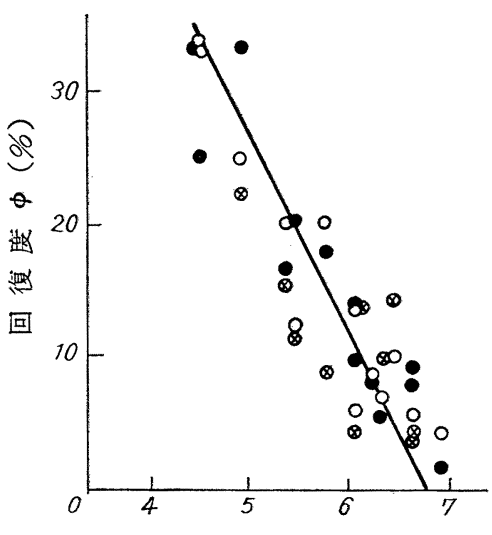

伸 長 $\gamma_{r}(\%)$

（第 7 図）除荷伸長と回復度との関係

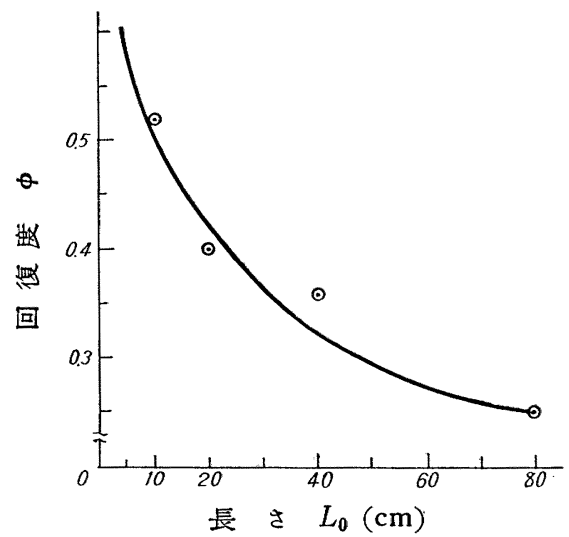

（第 8 図）試長と回復度との関係 


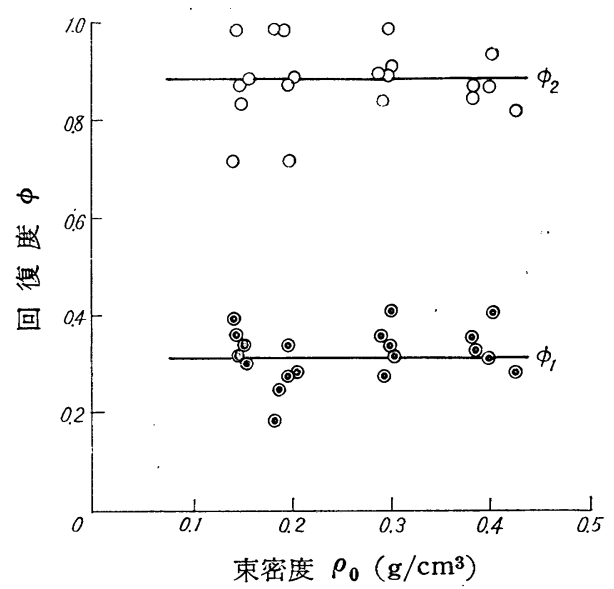

（第 9 図）スライバの充実度と回復度との関係 ( $\phi_{1}$ は初回, $\phi_{2}$ は 2 回目のサイクル)

なると，束内繊維は雨端が掴まれる機会が多くなり，摩 擦的にずるものが少なくなって弾性伸長をするものが多 くなる結果と考えられる. さらに充実度 $(1-\varepsilon)$ の值 に対しては申の值はほとんど変化しない（第9図）.

\section{4 束のクリープ速度 $D$}

一定の荷重を与えた束は，荷重が小さい場合は弾性的 に伸長するが，荷重が大きくなると，わずかに瞬間伸長 したのち時間の経過とともに荷重の大いさで定まる速度 で定常的な伸長を続け，ついに切断する(第 10 図). こ の場合の主なる結果としては, 定常伸長速度 $D$ と荷重の

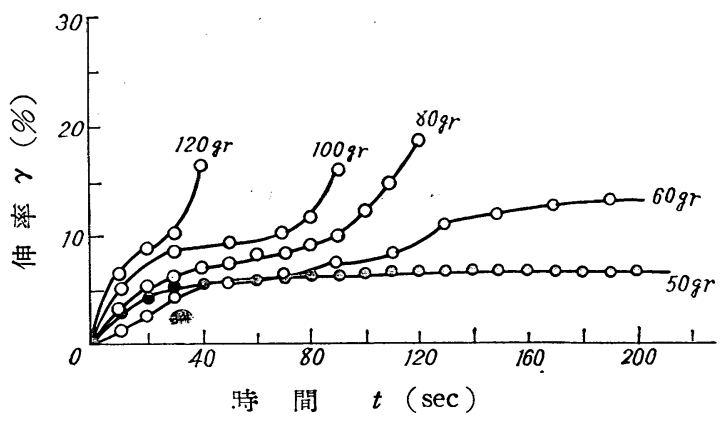

（第 10 図）スライバのクリープ曲線

大いさ $P$ との間に， $\alpha ， \beta$ を束の構造，とくに充実度

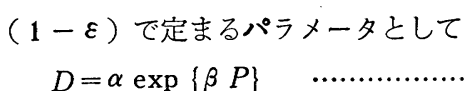$$
D=\alpha \exp \{\beta P\}
$$

の関係が実験的に成り立つ（第 11 図).乙れは定荷重を 与えた束内では繊維が緊張して張力が静摩擦力に達した とき付着が破れて滑りを起とし, 滑ると動摩擦力が働い て滑りが止んで付着を起とすという過程，すなわち束内

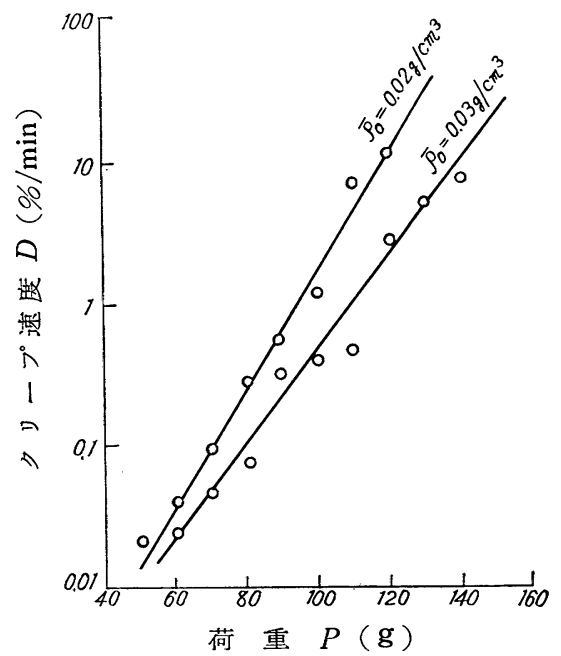

（第 11 図）定常クリープ速度と荷重との関係

繊維が Stick-Slip 運動を繰返す結果であると考えられ る. 事実, 単繊維の摩擦の場合にも Stick-Slip 運動が みられ，単繊維の引抜摩擦力 $F$ の多数の測定值の分布を 調べてみると，単繊維の張力が $F$ の大いさまでは束から 抜けずに，張力がちょうど $(F, F+d F)$ の間で引报か れるものの割合 $\mu(F)$ は

$$
\mu(F)=a \exp \{b F\}
$$

( $a, b$ は束の充実度 $(1-\varepsilon)$ で定まるパラメータ) の形となっている(第 12 図).

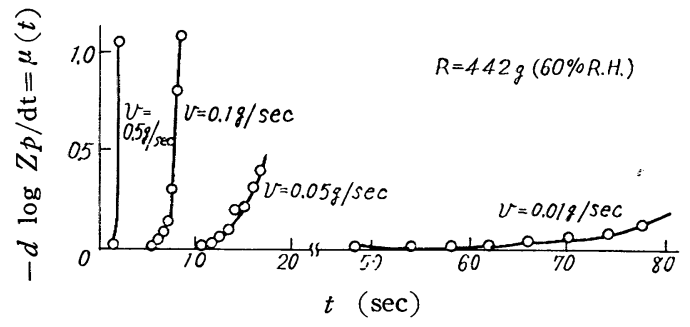

（第 12 図）束内絨維の滑脱の磪率々 引抜き速度の関係

\section{5. おわりに}

繊維の集合体は 1 つのシステムであって，与えられた 構造は情報の通信路であると考えれば，つぎのようなダ イヤグラムを描くことができる。

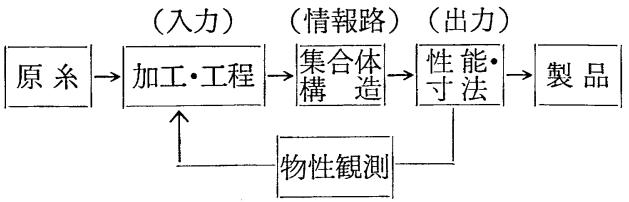


ここで重要なのは物性测定のフィードバックであっ て，従来どちらかといえば基視されていたきらいがあ る・とれを行なうことによって

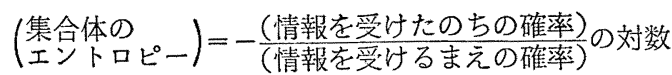
で定義される $d S$ は減少する.その結果として, 集合体 の伝える情報の価值 $T=d Q / d S$ は目的関数 $d Q$ 亿対 して増大するととが期待される．Tは集合効果の測度で あって, エネルギ的分野とエントロピ一的分野の相反す る内容を同時に含むあのである.

繊維集合体の工学をシステム工学として体系化し，そ
の論理を整え，特殊性の説明をむ可能にすることが今後 の課題となろう.

\section{文献}

1 ) 木下, 行方; 絨学誌, 14, 288 (1958)

2) 伊東, 木下; 高分子, 14, 1065 (1965)

3) P.C. Carman; Flow of Gases Through Porous Media (1956)

4 ) 堀越; 綫学誌, 11, 255 (1955)

5 ) 堀越, 木下; 絾学誌, 13, 801 (1957)

6 ) 木下; 䋳学誌, 18, 1107 (1962), 19, 982 (1963)

7 ) 木下, 滝沢; 緘学誌, 17, 89 (1961)

\section{討論会記録}

〔質問 1】デニールと空隙との関係はどうか. 巻縮が かかった時など

〔回 答〕集合体の空陌率は，集合状態をどのように 指定するかに応じて，要素繊維の太さに関係する，た とえば単位体積当たりの繊維本数が指定されている集 合体では，空吵率は繊維の太さが細くなるほど大とな る.また緎維相互間の接触圧力が一定となるように集 合させたときにはややはり繊維が細いほど空妳率は大 きい. 繊維に巻緮のある場合には，その程度によって 単位体積当たりの繊維数（あるいは繊維 1 本当たりの 見かけ密度）が減少することを考慮して計算すればよ い. なお空隙率が一定のとき, 空隙の Pore-Size は繊 維の太さに比例する. 集合体の空隙という概念に対し て, 定量的には空吵率, 空隚の Pore-Size, 一定の Pore-Size を有する空吵の数などを区別して用いるこ とが望ましい。

〔質問 2】瀻維間のずきま紡績性の関係はどうか 〔回 答〕すきまの多い集合体ではそれが少ないもの に比べて, 紡績上はつぎの 2 つ利点が考えられる. 第 1 点として, 巻縮などのために空陌の Pore-Size が 大きいと, 集合体からの単繊維の引抜力は周期の大き な Stick-Slip 運動を行なう.すなわち静摩擦力に比 ベて動摩擦力が小さいので, ドラフトゾーンにおい て低速繊維は高速化の機会が少なく, 速度変換点はフ ロントローラに近くなる，第 2 に，空隙の大きな集 合体では要素繊維の End-to-End Distance は加圧な ぞによって容易に伸長変形を起てしやすい. その結 果, ドラフトゾーン中で Tuft-Diagram は後端より も前端において, 繊維端のずれが大のものとなる.し たがってドラフト効果が増大する．欠点としては集束
性が低下し, 浮遊繊維が多くなることが予想される。

[啠問 3]応力一変形曲線の挙動加ら空隚効果を評価 しているが, 変形速度にはなぜ触れぬのか

〔回 答〕時間の都合で触れなかったが, 定まった組 成からなるスライバ状集合体の荷重一伸長曲線は，そ の空隙率の相違によって異なると同様に, 伸長速度に 対しても変化する. てれは束の応力一変形曲線の主要 部は束内から単纎維を引抜くときの摩擦力の総和とし て解析可能であり, この摩擦力は空谅率と引抜速度の 関数となるからである. 実験によれば引抜力は束の充 実度に比例し, 引抜速度の対数に比例する. したがっ て束の強力も近似的には引抜速度の対数に比例して増 大する. 束内繊維の引抜力が脨度の大きいほど大きく なるのは，滑抜には時間おくれがあるために速度が大 きいほど滑抜時の繊維張力が静摩擦力を越えて, より 大きな值となるためである・

〔質問 4〕 スライバの延伸特性に関する要因は充実度 だけでよいか. 繊維の異なる場合, 巻縮したトウの延 伸なども含めて, スライバ, トウの特性表示法につい て説明されたい

〔回 答〕集合体の延伸特性, 紡績性などの複合過程 はその素過程による解析がない限り 1 つの代用值で表 示することはできないと考える．たとえば，スライバ の延伸性についてみても, 上述の荷重一伸長曲線は弾 性域, 摩擦域, 切断域の $3 つ$ 領域に区別され, それ ぞれの素過程は異なっている. 弾性域は要素繊維のク リンプの 伸長であって束の 充実度 (空隙率) によら ず, 繊維自身の形態（コンフォーメーション）に依存 する.摩擦域は引抜力の総和であるから束の空隙率, 配列度, 変形速度に主として関係し, 切断域において 
は接触の欠宿の存在確率が支配的であるため, 以上の

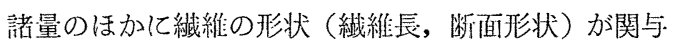

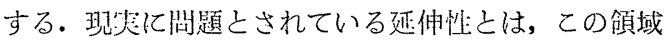
のうちのいずれにもっとも対応するかを見きわめた上 で（たとえば巻縮したトウでは延伸過程ではクリンプ が伸びきっていないかどうか）試料の加重一伸長曲線 を手がかりとして, 延伸特性の解析を行なうことがで きるであろう。

〔質問 5】無撚の繊維集合体（スライバ）の集束性と いうかまとまりは, 䋐維の摩擦, 巻縮などにより異な り，プロセシングの難易に影響することがある．スラ イバの集束性を定量的に，しかも簡単に測定する方法

负

次

\section{（c）繊維塊の厚さと構造}

東洋紡 績

\section{1. 緒}

击

ここでは繊維塊としては, 一応 ローラ カード上がり のウエブを対象とし，それに関するいくらかの問題につ いて筆者のてれまで行なってきた研究を，簡単にまとめ て記すととにする。

繊維塊の圧縮変形曲線の研究はいままで多くの報告が なされているが，その大部分はデータの数式化にとどま っているので, 庄縮変形を構成繊維の性質や, 集合形態 と結びつけた検討はあまり行なわれていないようであ る. van Wyk はこの問題の理論的な研究として有名で あるが，（1）圧縮変形によって生じる繊維の配向効果 をまったく無視していること,（2）瀻維間の接触があ っぱらランダムに分布している繊維同志の間の排除体積 的な効果によって決定されるという仮定をしているとと から, その理論の適用範囲はごく初期的な変形領域に限 定され，またとの理論によって導かれた式は，実測曲線 とあまりよく一致はしないようである，ててではまず， 繊維の性質ならびに集合形態と結びついた圧縮変形曲線 の理論を述べるとにする。

つぎに種々の状態における繊維塊の比容積に触れ, つ
があれば示されたい

〔回 答〕集束性を定量的に㳩定するのは, 現在のと ころでは繰这し際摖を困率面で行なったのち，その切 断強度を測定する法（たとえば D. N. E. Cooper；

J. Text. Inst., 53, T94, 1962）であろう.ずべての Processing に共通して有効な测定法はまだないよう である。したがってスライバ状集合体の集束性につい ても, 集束性が悪いために起こるトラブルが, 応力集 中による部分切断か, トウの耳の揃わぬことか, 巻取 りのフレキシビリティの不良か, ローラ アップか等 々によって，それらの測定法も晎なり，対策む違って くるのではなかろうか.

疋
松尾達樹

いでこれら比容積が繊維の性質ならびに繊維の巻縮形状 とどのような関係があるかについて触れることにする。

最後に繊維塊の比容積（厚さ）を保持する能力と, そ れを決定する主要な要因に関して触れるととにする。

\section{2. 織維塊の圧縮変形}

ランダムに繊維が集まっておりさえすれば, その繊維 塊の比容積が自然に定まってくるというととは決してあ りえない.たとえば繊維長が無限に長く，適当な巻綰形 状を有し，完全剛体であるきわめて細い繊維塊を考える と, その比容積はいくらであ大きくすることができるは ずである.てのととからも推測されるようにある定まっ た繊維長, 繊維の曲げかたさ, 巻縮形状, デニール, 繊 維間の摩擦係数などの值をとる繊維が，ある定まった方 法でほぼ゙されて作られた繊維塊を指定するととによっ て，その比容積ははじめて定まってくるはずである，し かし比容積をてれらの諸要因と結びつけて理論的に計算 することはきわめて困難であるので, まず圧縮の初期状 態に対して比容積 Vo が与えられたものとして出発する ことにする。

繊維塊における繊維の集合形態はきわめて千差万別で 